\title{
GLOSSARY OF MAORI TERMS
}

The following glossary is intended as an indicative guide only, and is compiled from major published sources including Cleve Barlow, Tikanga Whakaaro: Key Concepts in Maori Culture (Auckland 1991), Roger Neich, Carved Histories: Rotorua Ngati Tarawhai Woodcarving (Auckland 2001), and Anne Salmond, Hui: A Study of Maori Ceremonial Gatherings (Auckland 2004).

\begin{tabular}{|c|c|}
\hline haka & posture dance \\
\hline hapu & a social division below the level of tribe \\
\hline hei-tiki & neck pendant in the form of a human figure \\
\hline hongi & $\begin{array}{l}\text { The hongi is a ritual of greeting, blessing, and unity. } \\
\text { The two parties press noses against one another and } \\
\text { exhale. }\end{array}$ \\
\hline kainga & unfortified Maori village \\
\hline kaumatua & elder, old man or woman \\
\hline kowhaiwhai & curvilinear pattern \\
\hline maihi & bargeboard of a house \\
\hline mana & $\begin{array}{l}\text { psychic force, authority, control, prestige, power, } \\
\text { influence }\end{array}$ \\
\hline mana whenua & the power associated with the possession of lands \\
\hline Maoritanga & concept of Maori identity, Maori culture \\
\hline marae & courtyard in front of a meeting house \\
\hline moko & incised body adornment, tattoo \\
\hline$p a$ & fortified Maori village \\
\hline pah & $\begin{array}{l}\text { common nineteenth and early twentieth-century } \\
\text { European spelling of 'pa' }\end{array}$ \\
\hline $\begin{array}{l}\text { Pakeha } \\
\text { pataka }\end{array}$ & $\begin{array}{l}\text { Person of European descent, as opposed to a Maori } \\
\text { raised storehouse }\end{array}$ \\
\hline poupou & side wall panel on the inside of a house \\
\hline raupo & a swamp reed \\
\hline tangi & funeral ceremony \\
\hline taonga & property, treasure, highly prized object \\
\hline tapu & sacred, under religious restriction \\
\hline tekoteko & carved figure atop the gable of a house \\
\hline tikanga & $\begin{array}{l}\text { customary rules or habits, a set of beliefs associated } \\
\text { with Maori cultural practices }\end{array}$ \\
\hline $\begin{array}{l}\text { toe-toe } \\
\text { tohunga }\end{array}$ & $\begin{array}{l}\text { a large native grass traditionally used for weaving } \\
\text { expert, in either religious or practical matters }\end{array}$ \\
\hline
\end{tabular}




\section{GLOSSARY OF MAORI TERMS}

urupa burial place

waka canoe, vessel or container

whare house

whare runanga meeting house

whare whakairo carved house 